\title{
Procalcitonin is useful in identifying bacteraemia among children with pneumonia
}

\author{
CRISTIANA M. NASCIMENTO-CARVALHO ${ }^{1}$, MARIA-REGINA A. CARDOSO $^{2}$, \\ ALDINA BARRAL ${ }^{3}$, CÉSAR A. ARAÚJO-NETO ${ }^{4}$, SYLVIE GUERIN ${ }^{5}$, \\ ANNIKA SAUKKORIIPI ${ }^{6}$, MIKA PALDANIUS $^{6}$, RAIJA VAINIONPÄÄ ${ }^{7}$, PIERRE LEBON ${ }^{5}$, \\ MAIJA LEINONEN ${ }^{6}$, OLLI RUUSKANEN ${ }^{8} \&$ DOMINIQUE GENDREL $^{5}$
}

\begin{abstract}
From the ${ }^{1}$ Paediatrics Department, Federal University of Bahia School of Medicine, Salvador, ${ }^{2}$ Epidemiology Department, Faculty of Public Health, São Paulo University, São Paulo, ${ }^{3}$ Pathology Department, Federal University of Bahia School of Medicine and Centro de Pesquisa Gonçalo Muniz, Fundação Oswaldo Cruz, Salvador, ${ }^{4}$ Image Diagnosis Department, Federal University of Bahia School of Medicine, Salvador, Brazil, ${ }^{5}$ Paris Descartes University-St Vincent-Cochin Hospital, Paris, France, ${ }^{6}$ National Institute for Health and Welfare, Oulu, Finland, ${ }^{7}$ Virology and ${ }^{8}$ Paediatrics Department at University of Turku, Turku, Finland
\end{abstract}

\begin{abstract}
Empirical antibiotic use is prescribed in managing children with pneumonia worldwide. We assessed the usefulness of procalcitonin (PCT) and interferon-alpha (IFN- $\alpha$ ) in differentiating viral from bacterial pneumonia. Among 159 hospitalized children, pneumonia was diagnosed based on clinical complaints plus pulmonary infiltrate. Aetiology was investigated for 9 viruses and 4 atypical and 3 typical bacteria. PCT and IFN- $\alpha$ were measured in the serum sample collected on admission. Eight patients had bacteraemic infections, 38 had non-bacteraemic typical infections, and 19 patients had atypical bacterial infections. Viral and unknown aetiology was established in $57(36 \%)$ and $34(21 \%)$ cases, respectively. Three patients with bacterial infection without collected blood culture were excluded. IFN- $\alpha$ (IU/ml) was detectable in $20(13 \%)$ cases. The difference among median PCT values of the bacteraemic $(4.22 ; 1.56-7.56)$, non-bacteraemic typical bacterial $(1.47 ; 0.24-4.07)$, atypical bacterial $(0.18 ; 0.06-1.03)$ and only viral $(0.65 ; 0.11-2.22)$ subgroups was significant $(p=0.02)$. PCT was $\geq 2 \mathrm{ng} / \mathrm{ml}$ in $52(33 \%)$ cases. The presence of IFN- $\alpha$ was associated with PCT $<2 \mathrm{ng} / \mathrm{ml}$ $(90 \%$ vs. $64 \%, p=0.02)$. The negative predictive value (95\% confidence interval) of PCT $\geq 2 \mathrm{ng} / \mathrm{ml}$ was $95 \%$ (89-100\%), 89\% (78-100\%), 93\% (85-100\%) for differentiation of bacteraemic from viral, atypical bacterial and nonbacteraemic typical bacterial infection, respectively, and 58\% (49-68\%) for differentiation between bacterial and viral infection. PCT may be useful in identifying bacteraemia among children hospitalized with community-acquired pneumonia. IFN- $\alpha$ was uncommonly detected.
\end{abstract}

\section{Introduction}

Community-acquired pneumonia (CAP) is the leading single cause of mortality in children aged less than $5 \mathrm{y}$, and 156 million new episodes are estimated to occur in this age-group each y, worldwide [1].Viral and bacterial pathogens can cause CAP [2]. In developing countries, empirical use of antibiotics is the routine management [3] because of the association between bacterial infection and childhood deaths attributable to CAP [4]. In developed countries, the administration of antibiotics is also empirical, based on the assessment of severity [5]. Nonetheless, viral infections among children with CAP have been recognized as more frequent than bacterial infections, all over the world [6]. Moreover, viral co-infections are frequent, and children with viral co-infections present as more severe cases than those with single viral infection, requiring hospitalization more frequently [7]. No clinical or radiological characteristic has been found to be helpful in the distinction between viral and bacterial infection in children with CAP [8]. We aimed to assess the usefulness of

Correspondence: C. M. Nascimento-Carvalho, Paediatrics Department, Federal University of Bahia School of Medicine, Rua Prof. Aristides Novis, No. 105/1201B, Salvador, CEP 40210-630, Bahia, Brazil. Tel:+55 71 32357869. Fax:+55 7133320725. E-mail: nascimentocarvalho@hotmail.com 
procalcitonin (PCT) and interferon-alpha (IFN- $\alpha$ ) in differentiating viral from bacterial infections among children with CAP.

\section{Materials and methods}

\section{Study design}

This prospective investigation was carried out at the Professor Hosannah de Oliveira Paediatric Centre, Federal University of Bahia, Salvador, Northeast Brazil, from September 2003 to May 2005. Enrolment was based on hospitalization due to the presence of pulmonary infiltrate read by an independent paediatric radiologist, respiratory complaints and fever or difficulty breathing. Exclusion criteria included HIV-infected mother, immunodeficiency, cancer, tuberculosis, measles, chickenpox or chronic pulmonary disease, except asthma.

\section{Collection of biological samples and laboratory tests}

On admission, nasopharyngeal secretions were aspirated and blood was collected for culture, buffy-coat and serum samples. A second blood sample was collected 2-4 weeks after recruitment for serological assays. Blood culture was immediately performed according to routine procedures. The other biological samples were kept frozen $\left(-20^{\circ} \mathrm{C}\right.$ : serum; $-70^{\circ} \mathrm{C}$ : buffy-coat and nasopharyngeal aspirates) until shipment to the research laboratories. The virological tests were performed in Turku, Finland. Respiratory virus investigation consisted of searching for viral antigens (influenza A and B viruses, respiratory syncytial virus, parainfluenza virus type 1,2 , and 3 , and adenovirus) using a time-resolved fluoroimmunoassay with monoclonal antibodies and the determination of virus-specific serum antibody titres in paired samples using an enzyme-immunoassay (EIA) with an antigen-coated solid phase and horseradish peroxidaseconjugated rabbit anti-human IgG [9]. Two reverse transcription-polymerase chain reaction (PCR) assays for the detection of rhinovirus and enterovirus were performed [10]. In addition to blood culture, bacterial infection caused by Streptococcus pneumoniae, non-typeable Haemophilus influenzae and Moraxella catarrhalis were investigated by antibody assays in paired serum samples [11]. PCR was used for the detection of S. pneumoniae DNA in blood buffycoat [12]. An in-house microimmunofluorescence test was used to measure IgG, IgA, and IgM antibodies to Chlamydia pneumoniae and Simkania negevensis [13]. Chlamydia trachomatis IgG antibodies were measured using a commercial, solid-phase EIA (Ani Labsystems Ltd, Vantaa, Finland). IgM antibodies to Mycoplasma pneumoniae were searched for using a commercial EIA kit (Platelia, Bio-Rad, Marnes La Coquette, France). Blood cultures were performed at the same hospital where patients were enrolled. Serology to M. pneumoniae was carried out at Fundação Oswaldo Cruz, in Brazil. The other bacterial tests were done in Oulu, Finland.

PCT concentration was measured by an immunoluminometric assay (LUMItest PCT, BRAHMS Diagnostica, Berlin, Germany) and the detection limit was $0.02 \mathrm{ng} / \mathrm{ml}$. IFN- $\alpha$ was measured with a biological assay using Madin-Darby bovine kidney (MDBK) cells and vesicular stomatitis virus as the challenge virus. The minimum IFN titre of $2 \mathrm{IU} / \mathrm{ml}$ was detectable in the assay. These measurements were performed in Paris, France.

\section{Study subjects}

The frequency of infection by each pathogen has been previously reported [14]. Additional acute serum samples were available for measuring PCT and IFN- $\alpha$ from 159 patients and were classified into 5 aetiological subgroups. The flow-chart presenting the aetiological subgroups is shown in Figure 1 . The bacteraemic infection subgroup comprised 8 cases of pneumococcal infection ( 1 isolated, 5 viral co-infection, 1 atypical bacterial and viral co-infection, 1 non-bacteraemic bacterial and viral co-infection). The non-bacteraemic typical bacterial infection subgroup consisted of 38 cases (17 isolated, 19 viral co-infection, 2 viral and atypical bacterial co-infection). The atypical bacterial infection subgroup comprised 19 cases (9 isolated, 10 viral co-infection). Out of the 10 patients without blood culture, 6 had no aetiology defined, 2 had typical bacterial and viral co-infection, 1 had viral and $1 \mathrm{had}$ atypical bacterial infection. These cases were excluded from the analysis since information on bacteraemia was missing. The 34 cases with negative results for all performed etiological tests formed the unknown subgroup.

\section{Statistical analysis}

PCT concentrations appeared as non-normally distributed and thus the results are presented as medians and $25^{\text {th }}-75^{\text {th }}$ percentiles. Kruskal-Wallis and Fisher's exact tests were performed. Sensitivity, specificity and predictive values (PV) were calculated. The receiver operating characteristic (ROC) curve was used to evaluate the ability of serum PCT concentrations to discriminate the different aetiological subgroups. Multivariate logistic regression was performed to analyze the association between PCT ( $\geq 2$ vs. $<2 \mathrm{ng} / \mathrm{ml}$ ) and aetiological subgroup (bacteraemic, non-bacteraemic, atypical bacterial, 


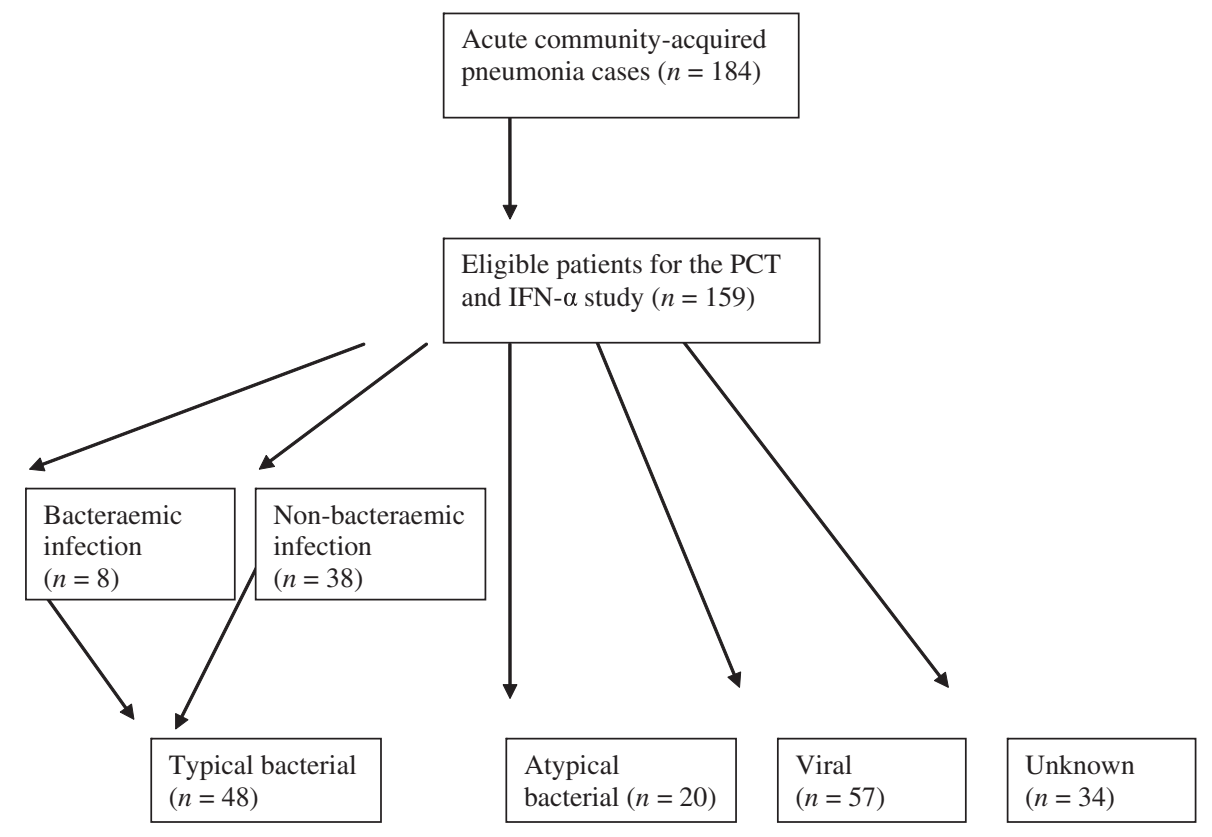

Blood culture was not collected from 2 out of 48 patients with typical bacterial infection and from 1 out of 20 with atypical bacterial infection.

Figure 1. Flow-chart showing the aetiological subgroups among children hospitalized with community-acquired pneumonia, in Salvador, Northeast Brazil.

viral) controlled for the children's age. The odds ratio $(\mathrm{OR})$ and $95 \%$ confidence interval $(95 \% \mathrm{CI})$ were calculated. The correlation between PCT concentration and age was assessed by the Spearman's correlation coefficient. The IFN- $\alpha$ data were analyzed as binomial variable.

\section{Results}

There were $95(60 \%)$ males and the mean age was 20 months ( \pm 14 , median 18 , range 26 days -4.8 y). Aetiology was bacterial in $28(18 \%)$, viral in $57(36 \%)$, viral-bacterial in $40(25 \%)$ and unknown in $34(21 \%)$. Table I shows the frequency of the aetiological agents detected. The median $\left(25^{\text {th }}-75^{\text {th }}\right.$ percentile) PCT $(\mathrm{ng} / \mathrm{ml})$ was $0.72(0.13-3.04) . \mathrm{IFN}-\alpha(\mathrm{IU} / \mathrm{ml})$ was detectable in $20(13 \%)$ cases. The difference among median PCTs of the bacteraemic $(4.22 ; 1.56-7.56)$, non-bacteraemic typical bacterial (1.47;0.24-4.07), atypical bacterial $(0.18 ; 0.06-1.03)$ and only viral $(0.65 ; 0.11-2.22)$ subgroups was significant $(p=0.02)$. PCT was $\geq 2 \mathrm{ng} / \mathrm{ml}$ in $52(33 \%)$ cases. There was no correlation between PCT and age $\left(\mathrm{r}_{\mathrm{s}}=+0.14\right.$, $p=0.09$ ). The presence of IFN- $\alpha$ was associated with PCT $<2 \mathrm{ng} / \mathrm{ml}(90 \%$ vs. $64 \%, p=0.02)$.

The ROC curve for PCT to separate bacteraemic from viral, atypical bacterial and non-bacteraemic typical bacterial infections had an area under the curve (AUC) $(95 \% \mathrm{CI})$ of $0.80(0.65-0.94), 0.88$
(0.75-1.0), 0.73 (0.54-0.92), respectively (cut-off $3.28 \mathrm{ng} / \mathrm{ml}$ ) and to separate non-bacteraemic typical bacterial from viral infections of $0.64(0.53-0.75)$ (cut-off $1 \mathrm{ng} / \mathrm{ml}$ ). From the logistic regression model, including aetiological group and age, the likelihood of having PCT $\geq 3.28 \mathrm{ng} / \mathrm{ml}$ in patients with bacteraemic or atypical bacterial infection was significantly different from patients with viral infection (OR 6.72, 95\% CI 1.20-37.59 and OR 0.13, 95\% CI 0.02-0.76, respectively). The results were the same when a cutoff point of $2 \mathrm{ng} / \mathrm{ml}$ was used (data not shown).

Table II presents the validity of different PCT cut-off points in differentiating viral from bacterial infections. The negative predictive value $(95 \%$ CI) of PCT $\geq 2 \mathrm{ng} / \mathrm{ml}$ was $95 \%$ (89-100\%), $89 \%$ (78-100\%), 93\% (85-100\%) for differentiation of bacteraemic infection from viral, atypical bacterial and non-bacteraemic typical bacterial infections, respectively, and 58\% (49-68\%) for differentiation between bacterial and viral infection. The presence of IFN- $\alpha$ did not add any increment to PCT in distinguishing between the different aetiological groups (data not shown).

\section{Discussion}

Procalcitonin increases dramatically in severe bacterial infections while it remains low in viral infections $[15,16]$. In lower respiratory tract infections, PCT is 
Table I. Frequency of the aetiological agents detected among children with community-acquired pneumonia hospitalized in Salvador, Northeast Brazil in whom procalcitonin was investigated.

\begin{tabular}{lrc}
\hline & \multicolumn{2}{c}{ Frequency } \\
\cline { 2 - 3 } Aetiological agents & Overall & Unique agent \\
\hline Typical bacteria & & \\
$\quad$ Streptococcus pneumoniae & 34 & 13 \\
Haemophilus influenzae & 13 & 3 \\
$\quad$ Moraxella catarrhalis & 4 & 2 \\
Atypical bacteria & & \\
Mycoplasma pneumoniae & 11 & 5 \\
Chlamydia trachomatis & 9 & 1 \\
Simkania negevensis & 2 & 0 \\
Chlamydia pneumoniae & 1 & 19 \\
Viruses & & 12 \\
Rhinovirus & 33 & 8 \\
Respiratory syncytial virus & 26 & 7 \\
Parainfluenza & 25 & 3 \\
Influenza & 19 & 1 \\
Enterovirus & 7 & \\
Adenovirus & 6 & \\
\hline
\end{tabular}

very high in pneumococcal pneumonia with bacteraemia [17-19] and remains the best predictor of bacteraemia in children as in adults. Among hospitalized children, PCT $\geq 2.0 \mathrm{ng} / \mathrm{ml}$ showed specificity $\geq 80 \%$ for bacterial pneumonia [20]. Its prognostic value in respiratory infections is always difficult to establish because of the great number of possible pathogens (typical and atypical bacteria, viruses), the importance of co-infections and the lack of specificity of serological methods to prove an acute infection. Among adults, PCT guidance substantially contributes to reduce non-useful antibiotic therapy in patients managed in the emergency department for respiratory infection [21]. Recently, it was proposed to exclude patients with low PCT levels from trials on CAP because they are unlikely to benefit from antibiotic therapy [22].

To the best of the authors' knowledge, this is the first CAP study enrolling children with typical bacterial infection divided into 2 subgroups (bacteraemic and non-bacteraemic typical bacterial) in addition to children with atypical bacterial or viral infections. Based on the aforementioned results, we can observe that patients with bacteraemic pneumonia presented significantly higher PCT levels in comparison to patients with non-bacteraemic typical bacterial, atypical bacterial or viral infections. Moreover, from the logistic regression analysis, we can conclude that patients with atypical bacterial infection presented significantly lower PCT levels in comparison with patients with viral infection. These findings make it possible to infer that if one compares children with CAP with non-bacteraemic typical bacterial and atypical bacterial infections with viral infection, any significant difference will

Table II. Validity coefficients (95\% CI) of different procalcitonin cut-off points in differentiating viral from bacterial community-acquired pneumonia among children hospitalized in Salvador, Northeast Brazil.

\begin{tabular}{|c|c|c|c|c|}
\hline Cut-off points & Sensitivity \% & Specificity $\%$ & PPV \% & NPV \% \\
\hline \multicolumn{5}{|c|}{ Viral vs. bacteraemic } \\
\hline$\geq 0.1 \mathrm{ng} / \mathrm{ml}$ & 100 & $21(11-32)$ & $15(7-24)$ & 100 \\
\hline$\geq 0.12 \mathrm{ng} / \mathrm{ml}$ & 100 & $25(14-36)$ & $16(7-25)$ & 100 \\
\hline$\geq 0.25 \mathrm{ng} / \mathrm{ml}$ & 100 & $39(27-51)$ & $19(9-29)$ & 100 \\
\hline$\geq 0.5 \mathrm{ng} / \mathrm{ml}$ & 100 & $45(33-57)$ & $21(11-30)$ & 100 \\
\hline$\geq 1.0 \mathrm{ng} / \mathrm{ml}$ & $75(64-86)$ & $57(45-69)$ & $20(10-30)$ & $94(88-100)$ \\
\hline$\geq 1.8 \mathrm{ng} / \mathrm{ml}$ & $75(64-86)$ & $66(54-78)$ & $24(13-34)$ & $95(89-100)$ \\
\hline$\geq 2.0 \mathrm{ng} / \mathrm{ml}$ & $75(64-86)$ & $66(54-78)$ & $24(13-34)$ & $95(89-100)$ \\
\hline \multicolumn{5}{|c|}{$\begin{array}{l}\text { Viral vs. non-bacteraemic } \\
\text { typical bacterial }\end{array}$} \\
\hline$\geq 0.1 \mathrm{ng} / \mathrm{ml}$ & $96(92-100)$ & $23(15-31)$ & $51(42-61)$ & $87(80-93)$ \\
\hline$\geq 0.12 \mathrm{ng} / \mathrm{ml}$ & $90(84-95)$ & $26(18-35)$ & $51(41-60)$ & $75(67-83)$ \\
\hline$\geq 0.25 \mathrm{ng} / \mathrm{ml}$ & $81(74-89)$ & $40(31-50)$ & $53(44-63)$ & $72(63-80)$ \\
\hline$\geq 0.5 \mathrm{ng} / \mathrm{ml}$ & $73(64-81)$ & $46(36-55)$ & $53(43-63)$ & $67(58-76)$ \\
\hline$\geq 1.0 \mathrm{ng} / \mathrm{ml}$ & $65(55-74)$ & $58(48-67)$ & $56(47-66)$ & $66(57-75)$ \\
\hline$\geq 1.8 \mathrm{ng} / \mathrm{ml}$ & $46(36-55)$ & $67(58-76)$ & $54(44-63)$ & $59(50-69)$ \\
\hline$\geq 2.0 \mathrm{ng} / \mathrm{ml}$ & $44(34-53)$ & $67(58-76)$ & $52(43-62)$ & $58(49-68)$ \\
\hline \multicolumn{5}{|c|}{ Viral vs. atypical bacterial } \\
\hline$\geq 0.1 \mathrm{ng} / \mathrm{ml}$ & $60(49-71)$ & $23(13-32)$ & $21(12-31)$ & $62(51-73)$ \\
\hline$\geq 0.12 \mathrm{ng} / \mathrm{ml}$ & $60(49-71)$ & $26(16-36)$ & $22(13-32)$ & $65(55-76)$ \\
\hline$\geq 0.25 \mathrm{ng} / \mathrm{ml}$ & $40(29-51)$ & $40(29-51)$ & $19(10-28)$ & $66(55-76)$ \\
\hline$\geq 0.5 \mathrm{ng} / \mathrm{ml}$ & $30(20-40)$ & $46(34-57)$ & $16(8-24)$ & $65(54-76)$ \\
\hline$\geq 1.0 \mathrm{ng} / \mathrm{ml}$ & $25(15-35)$ & $58(47-69)$ & $17(9-26)$ & $69(58-79)$ \\
\hline$\geq 1.8 \mathrm{ng} / \mathrm{ml}$ & $10(3-17)$ & $67(56-77)$ & $10(3-16)$ & $68(57-78)$ \\
\hline$\geq 2.0 \mathrm{ng} / \mathrm{ml}$ & $10(3-17)$ & $67(56-77)$ & $10(3-16)$ & $68(57-78)$ \\
\hline
\end{tabular}

PPV, positive predictive value; NPV, negative predictive value. 
hardly be found. It is much easier to find differences in low PCT levels (e.g. $0.12 \mathrm{ng} / \mathrm{ml}$ ) studying children with fever and no focus of infection because the methods to diagnose bacterial infection are mainly dependent on the performance of cultures to investigate invasive bacterial disease [23]. The use of serological methods to diagnose non-bacteraemic respiratory infections has not been sufficiently validated because of the lack of a gold standard. For example, carriage acquisition of a new pneumococcal serotype may induce significant antibody production but it has been found in $<1 \%$ to $3 \%$ of non-symptomatic children [24]. Therefore, the detection of 38 (24\%) non-bacteraemic typical bacterial infections out of 159 CAP cases highly suggests probable typical bacterial infections. Only nine viruses were searched for and this must be recognized as another limitation.

IFN- $\alpha$ is secreted by many cells during viral infection [25]. The association found between detection of IFN- $\alpha$ and PCT level $<2 \mathrm{ng} / \mathrm{ml}(p=0.02)$ is in accordance with a previous report that secretion of IFN- $\alpha$ was more frequent in viral-infected patients than in bacterial-infected patients [16]. Nevertheless, adding information on detection of IFN- $\alpha$ did not improve the performance of PCT levels in distinguishing children with viral from bacterial pneumonia because the presence of IFN- $\alpha$ was uncommon (13\%).

From this data we can conclude that PCT may be useful in identifying bacteraemic infections among children hospitalized with CAP. Nonetheless, from a management point of view, it is of no help in distinguishing which children with CAP should receive antibiotics.

\section{Acknowledgements}

This study was supported by funding from the Fundação de Amparo à Pesquisa no Estado da Bahia (FAPESB), Salvador, Brazil and the Paediatric Research Foundation, Helsinki, Finland. C.M.N.-C., M.-R.A.C. and A.B. are investigators of the Brazilian Council for Science and Technology Development (CNPq).

Ethics statement: The study protocol was approved by the Ethics Committee of the Federal University of Bahia and by the Brazilian National Research Ethics Committee. Informed consent was obtained before study enrolment.

Declaration of interest: No conflict of interest to declare.

\section{References}

[1] Rudan I, Boschi-Pinto C, Biloglav Z, Mulholland K, Campbell H. Epidemiology and etiology of childhood pneumonia. Bull World Health Organ 2008;86:408-16.

[2] Nascimento-Carvalho CM. Etiology of childhood community acquired pneumonia and its implications for vaccination. Braz J Infect Dis 2001;5:87-97.

[3] World Health Organization. Integrated management of childhood illness. Chart booklet WC 503.2. Geneva: WHO; 2008. Available at: http://whqlibdoc.who.int/publications/ 2008/9789241597289_eng.pdf (accessed January 15, 2009).

[4] Shann F. Etiology of severe pneumonia in children in developing countries. Pediatr Infect Dis J 1986;5:247-52.

[5] Hale KA, Isaacs D. Antibiotics in childhood pneumonia. Pediatr Resp Rev 2006;7:45-51.

[6] Peltola V, Ruuskanen O. Respiratory viral infections in developing countries: common, severe, and unrecognized. Clin Infect Dis 2008;46:58-60.

[7] Cilla G, Onate E, Perez-Yarza EG, Montes M, Vicente D, Perez-Trallero E. Viruses in community-acquired pneumonia in children aged less than 3 years old: high rate of viral coinfection. J Med Virol 2008;80:1843-9.

[8] Korppi M, Don M, Valent F, Canciani M. The value of clinical features in differentiating between viral, pneumococcal and atypical bacterial pneumonia in children. Acta Paediatr 2008;97:943-7.

[9] Mäkelä MJ, Puhakka T, Ruuskanen O, Leinonen M, Saikku $P$, Kimpimäki $M$, et al. Viruses and bacteria in the etiology of the common cold. J Clin Microbiol 1998;36:539-42.

[10] Hyypiä T, Puhakka T, Ruuskanen O, Mäkelä M, Arola A, Arstila P. Molecular diagnosis of human rhinovirus infection: comparison with virus isolation. J Clin Microbiol 1998;36: 2081-3.

[11] Juvén T, Mertsola J, Waris M, Leinonen M, Meurman O, Roivainen $\mathrm{M}$, et al. Etiology of community-acquired pneumonia in 254 hospitalized children. Pediatr Infect Dis J 2000;19:293-8.

[12] Saukkoriipi A, Palmu A, Kilpi T, Leinonen M. Real-time quantitative PCR for the detection of Streptococcus pneumoniae in the middle ear fluid of children with acute otitis media. Mol Cell Probes 2002;16:385-90.

[13] Korppi M, Paldanius M, Hyvarinen A, Nevalainen A. Simkania negevensis and newly diagnosed asthma: a casecontrol study in 1- to 6-year-old children. Respirology 2006; 11:80-3.

[14] Nascimento-Carvalho CM, Ribeiro CT, Cardoso MR, Barral A, Araújo-Neto CA, Oliveira JR, et al. The role of respiratory viral infections among children hospitalized for community-acquired pneumonia in a developing country. Pediatr Infect Dis J 2008;27:939-41.

[15] Assicot M, Gendrel D, Carsin H, Raymond J, Guilbaud J, Bohuon C. High serum procalcitonin concentrations in patients with sepsis and infection. Lancet 1993;341:515-8.

[16] Gendrel D, Raymond J, Coste J, Moulin F, Lorrot M, Guérin S, et al. Comparison of procalcitonin with C-reactive protein, interleukin 6 and interferon-alpha for differentiation of bacterial vs. viral infections. Pediatr Infect Dis J 1999; 18:875-81.

[17] Moulin F, Raymond J, Lorrot M, Marc E, Coste J, Iniguez $\mathrm{JL}$, et al. Procalcitonin in children admitted to hospital with community acquired pneumonia. Arch Dis Child 2001;84: 332-6.

[18] Prat C, Domínguez J, Rodrigo C, Giménez M, Azuara M, Jiménez $\mathrm{O}$, et al. Procalcitonin, C-reactive protein and leukocyte count in children with lower respiratory tract infection. Pediatr Infect Dis J 2003;22:963-8. 
[19] Müller B, Harbarth S, Stolz D, Bingisser R, Mueller C, Leuppi J, et al. Diagnostic and prognostic accuracy of clinical and laboratory parameters in community-acquired pneumonia. BMC Infect Dis 2007;7:10.

[20] Toikka P, Irjala K, Juvén T, Virkki R, Mertsola J, Leinonen $\mathrm{M}$, et al. Serum procalcitonin, C-reactive protein and interleukin-6 for distinguishing bacterial and viral pneumonia in children. Pediatr Infect Dis J 2000;19: 598-602.

[21] Christ-Crain M, Stolz D, Bingisser R, Müller C, Miedinger D, Huber PR, et al. Procalcitonin guidance of antibiotic therapy in community-acquired pneumonia: a randomized trial. Am J Respir Crit Care Med 2006;174:84-93.
[22] Niederman MS. Biological markers to determine eligibility in trials for community-acquired pneumonia: a focus on procalcitonin. Clin Infect Dis 2008;47(Suppl 3):S127-32.

[23] Maniaci V, Dauber A, Weiss S, Nylen E, Becker KL, Bachur R. Procalcitonin in young febrile infants for the detection of serious bacterial infections. Pediatrics 2008;122:701-10.

[24] Korppi M, Leinonen M, Ruuskanen O. Pneumococcal serology in children's respiratory infections. Eur J Clin Microbiol Infect Dis 2008;27:167-75.

[25] Price GE, Gaszewsk-Mastarlarz A, Moskophidis D. The role of alpha/beta and gamma interferons in development of immunity to influenza A virus in mice. J Virol 2000;74: 3996-4003. 